This item was submitted to Loughborough's Research Repository by the author.

Items in Figshare are protected by copyright, with all rights reserved, unless otherwise indicated.

\title{
Availability of monitored hourly building performance data for validating dynamic thermal models of buildings
}

PLEASE CITE THE PUBLISHED VERSION

https://doi.org/10.1177/014362449101200203

\section{PUBLISHER}

(c) Chartered Institution of Building Services Engineers

\section{VERSION}

VoR (Version of Record)

\section{PUBLISHER STATEMENT}

This work is made available according to the conditions of the Creative Commons Attribution-NonCommercialNoDerivatives 4.0 International (CC BY-NC-ND 4.0) licence. Full details of this licence are available at: https://creativecommons.org/licenses/by-nc-nd/4.0/

\section{LICENCE}

CC BY-NC-ND 4.0

\section{REPOSITORY RECORD}

Lomas, Kevin J.. 2019. "Availability of Monitored Hourly Building Performance Data for Validating Dynamic Thermal Models of Buildings”. figshare. https://hdl.handle.net/2134/32608. 


\title{
Technical Note
}

Summary As part of the SERC/BRE sponsored exercise to develop tools for validating dynamic thermal models, Leicester Polytechnic undertook a review and evaluation of monitored structures to identify data sets suitable as the basis for empirical validation tools. Over 580 monitored buildings located throughout the world were classified and assessed; all had produced hourly building performance data and had associated weather data. Data from only 18 structures, located at six sites in Europe and the USA, were deemed to be of high enough quality that they could be used for validating a wide range of complex dynamic and simpler thermal models. This Note gives an overview of the evaluation procedure, the types of data available and the major conclusions of the research.

\section{Availability of monitored hourly building performance data for validating dynamic thermal models of buildings}

\author{
K J Lomas BSc PhD CEng MInstE \\ Leicester Polytechnic, School of the Built Environment, PO Box 143, Leicester LE1 9BH, UK
}

Received 5 March 1990, in final form 26 November 1990

\section{Introduction}

Leicester Polytechnic was one of four UK institutions collaborating in the joint Science and Engineering Research Council (SERC) and Building Research Establishment (BRE) project $A n$ investigation into analytical and empirical validation techniques for dynamic thermal models of buildings. ${ }^{(1)}$ This group was interested in models which predict the dynamic (hourly) variations in plant loads and energy fluxes rather than those which were aimed at simulating HVAC or active solar systems. Such models are often termed 'building load' or 'building envelope' models. It is models of this type which are the subject of this Note. The group worked with ESP, SERIRES and HTB2. The primary thrust of the work at Leicester Polytechnic was to generate tests (or tools) based on empirical validation, that is, the comparison of model predictions with data collected from monitored buildings.

To be of real value, these validation tools should be capable of revealing 'internal errors' in the models themselves, such as inappropriate simplifications of the real world, invalid mathematical approximations and coding errors. To do this, it is necessary to minimise 'external errors': in the data input to the models; in the measurement of the building's thermal behaviour; and in the procedure used to compare measured and predicted values. This is no easy task; in a recent review ${ }^{(2)}$ the author of this Note concluded that 'the presence of external errors (and the consequent uncertainty in model predictions) has meant that none of the previous empirical validation studies undertaken using ESP, SERIRES, DEROB and BLAST would have produced conclusive evidence of internal errors in the models themselves' and that 'only the highest quality building construction and datagathering techniques can hope to produce conclusive evidence of internal errors in dynamic thermal models'. An exhaustive search and evaluation procedure was therefore undertaken to try to uncover data sets which would enable a suite of validation tools to be generated, covering the widest possible range of building types, modes of operation and climatic types. The work has been documented in detail elsewhere ${ }^{(3,4)}$. The aim of this Note is to give an overview of the four-phase evaluation procedure, the data sets available, the information about each data set which has been collated and the overall conclusions of the research.

\section{Phase 1: Identifying acceptable data sets}

In Phase 1 preliminary acceptance criteria were devised to eliminate data sets which could not be of value for validating any dynamic thermal building envelope model.

\subsection{Criterion 1}

Structures must not include operative active solar space heating or cooling systems.

\subsection{Criterion 2}

The weather data must have been collected at the site of the building.

\subsection{Criterion 3}

The measured building performance data and the weather data must be available at hourly or more frequent intervals.

\subsection{Fulfilment of criteria}

Only data sets which fulfilled all three criteria were considered as a possible basis for empirical validation tools. These were termed 'acceptable data sets'.

\section{Phase 2: Search for and classification of acceptable} data sets

In Phase 2 the widest possible range of acceptable data sets were identified using a variety of methods. These included:

(a) interrogating 14 computerised literature data bases

(b) a questionnaire survey of the 21 members of the International Energy Agency Executive Committee for Buildings and Community Systems

(c) visits to data collection sites in the UK and North America 
(d) an extensive search of other standard sources, conference proceedings, journals etc.

The search revealed 589 different structures from which acceptable data had been gathered. As most of these had been monitored in a variety of configurations and modes of operation and under different weather conditions, the total number of acceptable data sets was very much larger. Detailed information was sought for 221 of these structures. On the basis of the limited information to hand at the time, these were thought likely to have yielded the best data. The details of the 221 structures were classified and tabulated individually ${ }^{(3,4)}$.

The remaining 368 structures were either residences or commercial buildings which had been monitored at what is commonly known in the USA as the Class B level. At this level, the basic 'building system level', parameters such as internal temperatures and power consumptions are recorded, but not 'mechanism level' data (i.e. the temperatures and heat fluxes which permit validation of individual model algorithms). These 368 structures were evaluated in Phases 3 and 4 on the basis of their common group characteristics.
The 221 classified buildings ranged in size from $1 \mathrm{~m}^{3}$ boxes to very large multi-storey commercial buildings, so six structural categories were devised. Data from structures in all six categories have been used for model validation. In general, the structures increase in complexity from Category 1 , Test cells, to Category 6 , Commerical buildings.

\subsection{Detailed reports}

The detailed reports ${ }^{(3,4)}$ provide the following information:

(a) an overview of the structures in each category, including their location, the purpose for which they were monitored, and an appraisal of the strengths and weaknesses of the data

(b) photographs depicting structures which typify those in each category

(c) detailed tabular information about each data set with further textual information where necessary.

The tables are the key to the classification process. They contain the same type of information about each structure to the same level of detail:

Table 1 Classification and general description of monitored structures

\begin{tabular}{|c|c|c|c|}
\hline Category & Sub-category & General description & Advantages/Disadvantages \\
\hline \multirow[t]{2}{*}{1 Test cells } & Los Alamos type & $\begin{array}{l}\text { Based on original Los Alamos Cells built } \\
\text { in } 1976 . \text { All in USA except for cells in } \\
\text { Peterborough, UK. Internal volume } 11 \mathrm{~m}^{3} \\
\text { approx. Insulated wooden frame } \\
\text { construction. Insulated party wall } \\
\text { separates cell pairs. In general, highly } \\
\text { glazed, well sealed, south facing. }\end{array}$ & $\begin{array}{l}\text { Cheap to build. Constructions well } \\
\text { defined. Built form easily changed. } \\
\text { Scaling problems in small cells. Easy } \\
\text { to model. Frequently used for model vali- } \\
\text { dation. }\end{array}$ \\
\hline & Custom designed & $\begin{array}{l}\text { All in Europe except single cell in } \\
\text { Colorado. Vary from } 1 \mathrm{~m}^{3} \text { wooden boxes to } \\
64 \mathrm{~m}^{3} \text { concrete cell. }\end{array}$ & \\
\hline
\end{tabular}

\begin{tabular}{|c|c|c|}
\hline $\begin{array}{l}2 \text { Experimental } \\
\text { rooms }\end{array}$ & - & $\begin{array}{l}\text { Unoccupied, monitored zone within, or } \\
\text { attached to, existing building. Wide } \\
\text { variety of locations and built forms. }\end{array}$ \\
\hline
\end{tabular}

\begin{tabular}{ll}
\hline $\begin{array}{l}\text { Indoor } \\
\text { structures }\end{array}$ & $\begin{array}{l}\text { Variety of structures located in large } \\
\text { environmental chambers. Vary from full } \\
\text { size to test boxes, all unoccupied }\end{array}$ \\
\hline
\end{tabular}

\begin{tabular}{lll}
\hline $\begin{array}{l}4 \text { Experimental } \\
\text { buildings }\end{array}$ & Zoned & $\begin{array}{l}\text { Unoccupied, built for research only. } \\
\text { Virtually all data post 1980. Similar }\end{array}$ \\
& $\begin{array}{l}\text { Thermally } \\
\text { integrated }\end{array}$ & $\begin{array}{l}\text { size actual residences. Some } \\
\text { buildings reconfigurable. Wide range of } \\
\text { forms. Frequent source of good } \\
\text { validation data. }\end{array}$
\end{tabular}

\begin{tabular}{|c|c|c|c|c|}
\hline 5 Residences & $\begin{array}{l}\text { Conventional } \\
\text { Passive solar }\end{array}$ & $\begin{array}{l}\text { Typical of region } \\
\text { in which located. } \\
\text { Contain overt } \\
\text { passive solar } \\
\text { (and hybrid) } \\
\text { features. }\end{array}$ & $\begin{array}{l}\text { Single family } \\
\text { dwellings not } \\
\text { substantially modified } \\
\text { for research. Most in } \\
\text { USA but } 6 \text { in UK. } \\
\text { Occupied, unoccupied } \\
\text { and sinulated } \\
\text { occupancy. Only } 3 \\
\text { monitored specifically } \\
\text { for model validation. }\end{array}$ & $\begin{array}{l}\text { Typify design usage of models. Occupancy } \\
\text { problematical. Ill-defined heat flow } \\
\text { mechanisms cannot be explicitly modelled. } \\
\text { Complex heating systems. }\end{array}$ \\
\hline $\begin{array}{l}6 \text { Commercial } \\
\text { buildings }\end{array}$ & - & \multicolumn{2}{|c|}{$\begin{array}{l}\text { Large, occupied, multi-zoned and often } \\
\text { multi-storey. Complex HVAC systems. } \\
\text { Sometimes used for validation. }\end{array}$} & $\begin{array}{l}\text { Very large, and complex. Dominated by } \\
\text { Internal gains. Numerous ill-defined } \\
\text { features. HVAC difficult to model }\end{array}$ \\
\hline
\end{tabular}


(i) General information about the institution responsible for the monitoring and the name and location of the experimental facility.

(ii) A description of the building, its constructional features, the mode of operation (the heating, cooling and venting strategy) and where appropriate, the type of occupancy, the number of rooms, the number of storeys and the plan area.

(iii) Details of the monitoring such as the recording period, the climatic and building response parameters recorded, and the media on which the data were stored.

(iv) The source references describing the experiments, the purpose of the monitoring and the uses which have been made of the data. Any usage of the data for empirical validation, especially by persons other than those who undertook the monitoring, is identified.

The compilation of information is thought to be the largest of its type ever assembled. In this Note it is only possible to give a brief overview (Table 1) and quantification (Table 2) of the structures in each category.

\section{Phase 3: Identifying useful data sets}

In this phase, criteria were derived to identify data sets which appeared to have deficiencies rendering them unsuitable for validating any dynamic thermal model. (The criteria were not therefore specific to any particular dynamic thermal model or group of such models). The data sets which pass these criteria were termed 'useful data sets'.

In the course of compiling the information about acceptable data sets, details of over 130 exercises involving comparisons between measured data and values predicted by thermal

Table 2 Number of structures remaining after each phase of the evaluation process

\begin{tabular}{|c|c|c|c|}
\hline \multirow[b]{2}{*}{$\begin{array}{l}\text { Structural category and } \\
\text { description }\end{array}$} & \multicolumn{3}{|c|}{ Number of data sets passing criteria } \\
\hline & $\begin{array}{l}\text { Phase } 1 \\
\text { Acceptable } \\
\text { data sets }\end{array}$ & $\begin{array}{l}\text { Phase } 3 \\
\text { Useful } \\
\text { data sets }\end{array}$ & $\begin{array}{l}\text { Phase } 4 \\
\text { High-quality } \\
\text { data sets }\end{array}$ \\
\hline \multicolumn{4}{|l|}{1 Test cells } \\
\hline Los Alamos Type & 40 & 8 & 2 \\
\hline Custom-Designed & 20 & 8 & 3 \\
\hline 2 Experimental rooms & 14 & 7 & $\mathbf{0}$ \\
\hline 3 Indoor structures & 7 & 5 & 0 \\
\hline $\begin{array}{l}4 \text { Experimental buildings } \\
\text { Zoned } \dagger \\
\text { Thermally Integrated }\end{array}$ & $\begin{array}{l}19 \\
41\end{array}$ & $\begin{array}{l}17 \\
25\end{array}$ & $\begin{array}{l}9 \\
4\end{array}$ \\
\hline $\begin{array}{l}5 \text { Residences } \\
\text { Conventional } \\
\text { Passive Solar \& Hybrid } \\
\text { Various groups } \ddagger\end{array}$ & $\begin{array}{r}49 \\
24 \\
313\end{array}$ & $\begin{array}{r}15 \\
5 \\
33\end{array}$ & $\begin{array}{l}0 \\
0 \\
0\end{array}$ \\
\hline $\begin{array}{l}6 \text { Commercial buildings } \\
\text { Individually Assessed } \\
\text { Various Groups } \ddagger\end{array}$ & $\begin{array}{r}7 \\
55\end{array}$ & $\begin{array}{l}0 \\
0\end{array}$ & $\begin{array}{l}0 \\
0\end{array}$ \\
\hline Totals & 589 & 123 & 18 \\
\hline
\end{tabular}

† Each structure may contain two or more thermally isolated zones; entry is total number of zones.

$\ddagger$ Additional data sets, from data bases and compilations, which were evaluated as a group. models, of varying complexity, were examined. In the vast majority of these exercises, a small number of factors were repeatedly highlighted as sources of major uncertainty. One or more of these external errors posed problems irrespective of the model being used and the type of structure from which the data had been collected.

The criteria were devised to eliminate data sets with these sources of external error.

\subsection{Criterion 4}

All three major elements of the weather, air temperature, wind speed and the direct and diffuse components of solar radiation, must be measured at the site of the building for the whole comparison period.

\subsection{Criterion 5}

The structure must be unoccupied, it must not contain passive solar features which cannot be explicitly modelled and each zone in the building must have independent heating and/or cooling plant and controls.

\subsection{Criterion 6}

Measured infiltration and, where appropriate, interzonal air flow rates, must be available for the whole comparison period.

\subsection{Fulfilment of criteria}

As the plant and air flow modelling capabilities of dynamic thermal models develop it should be possible to relax the restrictions imposed on the heating/cooling regimen (Criterion 5) and the air flow data (Criterion 6) so that currently 'unacceptable' data sets may become 'useful'.

At this stage, only data sets which definitely failed any one of the criteria were rejected. (Published sources of information often lacked crucial details.) In total, 90 of the 221 individually tabulated structures and 33 of the structures assessed on the basis of their group characteristics definitely passed the criteria (Table 2).

Data sets from residences and commercial buildings suffered a higher than average rejection rate; in fact, none of the commercial buildings passed all the criteria.

Since care was taken to avoid bias towards structures of a particular type or from a particular part of the world it is reasonable to assume that the data sets examined are a representative (and large) sample of all those which have been gathered. It may be concluded, therefore, that of all the data sets which appear to be acceptable for validating dynamic thermal load calculation models, only about $20 \%$ are actually likely to fulfil this purpose. This is unfortunate, particularly as many of the data sets which did not pass the criteria were gathered from experiments in which a major objective was to generate data suitable for model validation.

The main reason for the high failure rate stems from a conflict between the objectives of experiments where data were gathered for more than one purpose; there were many experiments of this type. It is clear that the limitations imposed by validation needs are, in general, far more stringent than those imposed by other objectives, e.g. building or component testing, energy use or energy saving evaluation, or thermal comfort assessment. Therefore, if data sets are to be used for model validation, the experimental constraints imposed by this objective should be given the 
highest priority. Any other approach is highly likely to produce data which will fail to fulfil this aim.

\section{Phase 4: Identifying high quality data sets}

In Phase 4, the aim was to select, from the useful data sets, those which were most appropriate as the basis for validation tools. The models used in the SERC/BRE research programme were deliberately chosen to cover a wide range of modelling capabilities and they are very demanding in their input requirements. Therefore, data sets which satisfy all three of these models are likely to be of use for validating many other models as well, especially simpler models.

Criteria were devised and applied to the useful data sets, and those which definitely passed these new criteria were termed 'high quality data sets'.

\subsection{Criterion 7}

The structure must not contain features, or environmental control systems, which cannot be modelled explicitly by ESP, HTB2 or SERIRES.

\subsection{Criterion 8}

The data medium must be of a type which is readily usable, and close liaison with the monitoring institution must be possible.

\subsection{Criterion 9}

Data which, due to external errors, have introduced unacceptable uncertainty into previous validation work, must not be used.

\subsection{Fulfilment of criteria}

The Phase 4 criteria eliminated all the remaining structures except for test cells and experimental buildings at just six sites in Europe and North America (Table 2). These eighteen structures were therefore deemed to have produced data sets which were of sufficiently high quality that they are likely to be suitable as the basis for widely applicable empirical validation tools.

Data were acquired from test cells in Peterborough (monitored by the Polytechnic of Central London) and the Passive Solar Test Facility experimental buildings (monitored by National Bureau of Standards in Washington DC). These data sets are now being used to empirically validate the dynamic thermal models at Leicester Polytechnic. Comparisons between these data and the predictions of the models are the subject of other publications.

\section{Conclusions}

\section{1}

A four-phase methodology has been devised to identify data sets suitable for validating dynamic thermal models. The classification procedure will also be useful to those who assess hourly on-site weather and building performance data for many other purposes.

\section{2}

An extensive literature search revealed over 589 structures which have been monitored in such a way that the data could be valuable for validating dynamic thermal models. These structures, located throughout the world, were all monitored in the last twenty years. They covered a wide variety of built forms and modes of operation. The structures were divided into six distinct categories and 221 of them are described in detail. This is thought to be the largest compilation of this type ever assembled.

\section{3}

Reference material, describing over 130 exercises in which thermal models have been compared with measured data, has been examined. In the most of these exercises the presence of a few easily identifiable sources of external error has severely undermined the value of the work, irrespective of the model being used or the type of building from which the data were acquired.

\section{4}

Criteria have been devised to exclude data sets which contain external errors which prevent them being useful for validating any dynamic thermal model. Only about $20 \%$ of the data sets reviewed passed these criteria, although many had been gathered for validation purposes. In future, monitoring experiments should be much more carefully conceived and executed if the data are to be of value for validating dynamic thermal models.

\section{5}

The limitations imposed on experimental designs by the requirements for validating dynamic thermal models are, in general, far more stringent than those imposed by any other monitoring objectives. Therefore, if data sets are to be used for model validation the constraints imposed by this objective should be given the highest priority.

\section{6}

Data from only six sites in Europe and the USA appeared to be of high enough quality to enable an accurate evaluation of the predictive ability of three of the models that were used by the SERC/BRE validation group, namely, ESP, SERIRES and HTB2. Data from the Polytechnic of Central London Test Cells and the US National Bureau of Standards Passive Solar Test Facility have been acquired as the basis for developing tools for empirical validation.

\section{7}

There are very few well documented high-quality data sets suitable for validating dynamic thermal models. In particular, there appear to be no such data from multi-zoned structures located in Western Europe.

\section{References}

1 Bloomfield D B Appraisal techniques for methods of calculating the thermal performance of buildings Building Serv. Eng. Res. Technol. 6(1) 13-20 (1985)

2 Bowman N T and Lomas $\mathrm{KJ}$ Empirical validation of dynamic thermal computer models of buildings Building Serv. Eng. Res. Technol. 6(4) 153-162 (1985)

3 Lomas $\mathrm{K} \mathrm{J}$ and Bowman N T An investigation into analytical and empirical validation techniques for dynamic thermal models of buildings SERC/BRE Collaborative Research Project Final Report Vol. 4 (Leicester Polytechnic School of Architecture) (1987)

4 Lomas K J A compilation and evaluation of building thermal performance data: With special reference to the validation of dynamic thermal models Technical Note (Building Performance Assessment Club) (1990) 